\title{
The History of Printing and Print Culture: contexts and controversies
}

\author{
John Hinks
}

Centre for Printing History and Culture, Birmingham City University, UK

john.hinks@bcu.ac.uk

Centre for Printing History and Culture, Birmingham City University, Room 423, Parkside

Building, Cardigan Street, Birmingham B4 7BD, UK.

\section{Biography}

John Hinks, formerly Director of Libraries and Information Service with Leicestershire County Council, took early retirement in 1997 and devoted more time to his longstanding interest in book history. His doctoral research focused on the history of printing and the book trade in Leicester until c.1850. Gaining his PhD from Loughborough University in 2002, he then worked as the Research Fellow on the 'British Book Trade Index on the Web' project at the University of Birmingham until 2005, since when he has held an honorary fellowship at the Centre for Urban History at the University of Leicester. He is currently also Honorary Research Fellow in Printing History and Culture at Birmingham City University, and an Honorary Research Fellow in the Centre for West Midlands History, University of Birmingham. He has published widely on print culture and book trade history, served several terms on the Council of the Bibliographical Society, chaired the Printing Historical Society from 2010 to 2019. He is currently a member of the executive group of the Centre for Printing History and Culture, a joint venture of Birmingham City University and the University of Birmingham. 


\title{
The History of Printing and Print Culture: contexts and controversies
}

\begin{abstract}
The history of printing and print culture is a dynamic and wide-ranging field of study, as the articles in this special issue demonstrate. By way of background, this Introduction briefly outlines the development of the field and highlights a number of controversial issues that have arisen within it. Although often considered part of 'the history of the book' (or 'book history'), much of the history of printing is concerned with the quotidian production of nonbook material including a vast variety of ephemeral printed items known as 'jobbing printing'. Printed items, both books and ephemera, have made a significant contribution to the history of the Midlands. In particular, printing played a key role in the industrial development of the region and in the 'Midlands Enlightenment'.
\end{abstract}

Keywords: printing history; print culture; book history; history of the book; printing revolution

The history of printing and print culture may seem on first encounter a narrow and rather esoteric field of study. However, as the articles in this special issue demonstrate, it is in fact a very wide-ranging field, full of interest for the specialist and non-specialist alike. The history of printing (and let us avoid tedious repetition by taking this to include print culture) has been studied for a long time now, from many different viewpoints, though at first not in a very systematic way, resulting in a patchwork quilt of studies of people (printers, booksellers, readers and many others), and of processes, machinery and typefaces. These have formed the preoccupation of most printing historians; collectively they provide us with an understanding of printing history from the perspective of the West - printing history being predominantly a western preoccupation.

This piecemeal approach was brought together - to some extent at least - during the latter half of the twentieth century when two related academic fields became established: 
printing history and 'book history' (or 'the history of the book' ${ }^{1}$ ). Printing history encompassed the history of printing techniques, type and typography, the design of printed material, printing technology and the social, cultural, industrial and economic histories of the trade. Printing history tended to be practised by printers and typographers, while book history presented itself as a more traditionally academic field, approached from a variety of angles by historians - especially, but not only, cultural historians — and by literary scholars, librarians, and many others. With hindsight, it seems surprising that the two fields were ever separate.

By the start of the present century, the boundaries between book history and printing history had become less apparent, and the two fields have recently grown together into a vibrant interdisciplinary field of study, approaching the topic of the creation (writing, manuscript, print, typography, graphic design, illustration, binding, etc.), distribution (publishing, bookselling, etc) and 'consumption' (reading and other methods of use) of the printed word — not only books — from many different starting-points. It has grown into a thriving interdisciplinary field of study, offering much to interest the non-academic reader as well as the specialist. As Rick Poynor noted recently, commenting on the history of graphic design — and it applies equally to printing history — the field:

urgently needs to be scrutinised by observers who are not graphic designers and can bring other disciplinary perspectives, social and ethnic backgrounds and life experiences to the discussion. While these initiatives might choose to take the nature of practice into account to achieve a nuanced understanding, they should not be constrained by professional concerns and objectives'.2

\footnotetext{
${ }^{1}$ I make no distinction between these terms, as some try to do (especially in North America), which just creates confusion. A seminal early text is L. Febvre and H-J.Martin, The Coming of the Book: the impact of printing 1450-1800 (first published in French, 1957; English translation, London: Verso, 1976).

${ }^{2}$ R. Poynor, 'Two cheers for publishing', Eye, 98 (2019), 100-101 (101).
} 
The aim of this Introduction is to set the scene for the articles that follow, by mentioning briefly some of the key developments in the growth of printing history, while highlighting some of the more controversial issues addressed by historians. ${ }^{3}$ One of the earliest controversies was a recognition that there had been an over-emphasis on the study of books and a consequent marginalization of the study of non-book items, documents and ephemera. Printing and book history are now taken to encompass, quite rightly, the study of many other printed (and handwritten) artefacts besides books, including both texts and images. ${ }^{4}$ A great deal, probably a majority, of printing activity has always been devoted to the production of items other than books; this is borne out by the articles in this issue, which focus mainly on printed material other than books. Advertising, labels, handbills, commercial stationery, and other 'jobbing' printing have been the staple of many printers' work and livelihood. James Raven has noted that the history of jobbing printing has often unwisely been neglected: 'jobbing was the life-blood of the printing house: it kept most printers going, and, in turn, wide-ranging jobbing output transformed the ways in which people did business and lived their lives'. ${ }^{5}$

Jobbing printing, in particular posters and display materials, are the focus of David Osbaldestin's innovative article on the early use of sans-serif types by some nineteenthcentury Midland printers. Guy Sjögren's article makes imaginative use of a range of primary sources to describe the importance of print to the marketing practices of Birmingham's cutnail trade. Birmingham is also the focus of Jenny Gilbert's article on the role of print in the

\footnotetext{
${ }^{3}$ These footnotes include suggestions for further reading for those who wish to explore printing history in more depth. In particular the seven volumes of The Cambridge History of the Book in Britain (Cambridge: Cambridge University Press, 1999-2019) are highly recommended.

${ }^{4}$ See for example J. Hinks and C. Armstrong, eds., Text and Image in the City: Manuscript, Print and Visual Culture in Urban Space (Newcastle upon Tyne: Cambridge Scholars Publishing, 2017). ${ }^{5}$ J. Raven, 'Print culture and the perils of practice', in The Perils of Print Culture: Book, Print and Publishing History in Theory and Practice, ed by J. McElligot and E. Patten (London: Palgrave Macmillan, 2014), pp. 218-237 (p. 230).
} 
wholesale fashion industry, which usefully discusses how clothing catalogues were used, as well as how they were printed.

This economic historical role of printing dates back to the late eighteenth century. A study that Maureen Bell and I carried out - to test the research potential of the online British Book Trade Index (BBTI $)^{7}$ —identified a significant increase in printing activity in provincial industrial towns in the last quarter of the eighteenth century:

This noticeable 'surge in printing' most probably resulted from printers meeting the growing needs of new and developing industries for printed matter (packaging, publicity, commercial stationery), rather than from a significant increase in book printing, though this rather broad assertion merits further research. ${ }^{8}$

The 'printing surge' in industrial towns was replicated in non-industrial towns after 1800. Previously, during the 'long eighteenth century', an increasing number of provincial printers had diversified into wide-ranging book-trade businesses, often including, alongside jobbing printing, the publication of a newspaper, the sale of books, periodicals, patent medicines, 'fancy goods', and sometimes much more. ${ }^{9}$ Ann Ireland, a notable printer and bookseller in Leicester, ran a thriving and very diverse business, as her advertisement from 1789 indicates:

At the Place of Sale may be had, Bibles and Common Prayer Books, in Morocco or other Bindings. Account Books and Ledgers of all Sorts, Rul'd or Plain, and Bound to

\footnotetext{
${ }^{7}$ BBTI was founded in 1983 by the late Professor Peter Isaac and his many collaborators. It was developed as an online resource, funded by the Arts and Humanities Research Council, at the University of Birmingham (2002-05). Dr Maureen Bell was the project director; I was the research fellow. BBTI is now hosted by the Bodleian Library: $<$ http://bbti.bodleian.ox.ac.uk $/>$ accessed 9 April 2020].

${ }^{8}$ M. Bell and J. Hinks, 'The English Provincial Book Trade: evidence from the British Book Trade Index' in The Cambridge History of the Book in Britain [hereafter CHoBB], vol. V: 1695-1830 (Cambridge: Cambridge University Press, 2009), pp. 335-51 (p. 347). For more detail of the BBTI research see J. Hinks and M. Bell, 'The Book Trade in English Provincial Towns, 1700-1849: an evaluation of evidence from the British Book Trade Index', Publishing History, 57 (2005), 53-1 12. ${ }^{9}$ J. Feather, The Provincial Book Trade in Eighteenth-Century England (Cambridge: Cambridge University Press, 1985).
} 
any Pattern or Order. Stationary ware of all kinds. A Capital Collection of Maps and Prints. Magazines, Reviews, and all other periodical publications. Blank Warrants and Precedents for Coroners, High-Constables, Justices Clerks \&c. \&c.

Music, Rul'd Music Paper, Harpsichord lessons, new songs, with every Article in the Musical Line. Letter Cases, Morocco, Spanish and Common Leather, with Straps or Clasps. Schoolmasters, and Country Shopkeepers, may be supplied with School books of all sorts - as also with Copy and Account Books, Quills, Pens, Black and Red Ink, Writing Paper of the best Quality \&c. \&c. On the Lowest Terms. Printing in General, executed with Neatness \& Dispatch - And Books bound in a Neat and Firm Manner, or in Elegant Bindings, on Reasonable Terms. ${ }^{10}$

The serious underplaying of the role of women in printing and the book trade is another area of controversy and is, thankfully, at last being rectified. There is, however, some way still to go: Sahar Afshar's article is the only one in this issue to mention a prominent book-trade female, Lorina Watkins, who ran a thriving bookbinding business in London in the mid-nineteenth century. Ann Ireland was unusual: widowed at an early age she took over her husband's very successful business, ran it on her own until her son came of age, and then ran it with him for many more years, although he was usually preoccupied with other interests including local politics. It is clear that his mother remained the leading light of this outstanding business, and that she developed it skilfully, diversifying into fashionable goods and services. Apart from widows trading on their own account, it has become increasingly clear that, despite their historical 'invisibility' (due to the prevailing social and cultural

\footnotetext{
${ }^{10}$ Ann Ireland, A Catalogue of Books... (Leicester, 1789), title-page. (Cambridge University Library: Munby Collection, d.136/2). For more information on Ann Ireland see J. Hinks, The History of the Book Trade in Leicester to c. 1850, unpublished PhD thesis (Loughborough University, 2002), pp. 220-230:

$<$ https://repository.lboro.ac.uk/articles/The history of the book trade in Leicester to c1850/94159 70/1> [accessed 9 April 2020].
} 
practices of the time and especially to legislation which regarded a married woman as her husband's property), many women were very active in printing and bookselling businesses, often taking a leading role in their day to day running while their husbands were busy with other projects. In recent years, the study of the various roles of women in printing and the book trades has gained ground. A major international conference, 'Women in Print', was organized by the Centre for Printing History and Culture (CPHC) in Birmingham in 2018. ${ }^{11}$ The conference attracted many excellent speakers and two edited collections are in preparation. $^{12}$

When Ann Ireland's husband died, his apprentice was turned over to her, making her one of the relatively few female 'masters' of apprentices. The system of freedom and apprenticeship was an important part of the printing and book trades, enabling skills to be passed on between generations. In Leicester, one of the old incorporated towns, the system was for the most part strictly enforced and diligently recorded. ${ }^{13}$ In the manorial towns, even large ones like Birmingham, there was no such system and anyone could try their hand at printing, bookselling, or any other trade for that matter. Caroline Archer-Parré's article discusses the importance not only of the passing on of printing skills but also, very interestingly, of the transfer of skills between different occupations. In Birmingham, a notable example of transferable skills was the connection between engraving (on metal

\footnotetext{
${ }^{11} \mathrm{CPHC}$ is a joint initiative between Birmingham City University and the University of Birmingham and consists of researchers, heritage professionals and librarians. It seeks to encourage research into all aspects and periods of printing history and culture, as well as education and training into the art and practice of printing: $<$ https://www.cphc.org.uk/ $>$ [accessed 9 April 2020].

${ }^{12}$ Women in Print 1: design and (re)construction of personal histories ed by R. Roberto and A. Alexiou; Women in Print 2: design and (re)construction of personal histories ed by H. S. Williams and C. Moog (Oxford: Peter Lang Ltd, forthcoming, in their 'Printing History and Culture' series, sponsored by CPHC).

${ }^{13}$ The system evolved from the medieval Merchant Guild of the town. See J. Hinks, 'Freedom and Apprenticeship Records as a Source for Book Trade History', Book Trade History Group Newsletter, 41 (December 2001): <https://www2.le.ac.uk/departments/urbanhistory/research/book-tradenetworks-files/freedom-and-apprenticeship $>$ [accessed 9 April 2020].
} 
goods, especially guns) and printing. John Grayson's article discusses another special skill, that of transfer printing onto enamelled artefacts. This is a fascinating story, informed not only by Grayson's historical research but also by his practical experience of carrying out some of the craft processes discussed.

Another controversy has been the contested definition and status of 'print culture' and its relationship with traditional printing history (with its emphasis on technology and design aspects). Print culture is concerned primarily with the social and cultural impact of the products of the printing press. However, the fact that there were books and other printed items around in a particular place and time does not of itself constitute print culture:

[...] print culture is not simply defined by the presence of books in a society, but in a widely diffused social knowledge of, and familiarity with, books and with the culture of buying, borrowing, lending, reading and handling these physical items. ${ }^{14}$

As James Raven explains:

The very use of the term 'print culture' is problematic and should remind those who concentrate upon historical aspects of the 'history of the book' (rather than critical bibliographical studies) that historians start with people, study people and make conclusions about people. ${ }^{15}$

These caveats are eminently sensible but it is worth adding that many historians, myself included, have never had any problem with the concept of print culture. The name of the Centre for Printing History and Culture was carefully chosen to include the history of print culture alongside other aspects of printing history. Each of the Centre's stated aims includes print culture:

\footnotetext{
${ }^{14}$ Perils of Print Culture, p. 5.

${ }^{15}$ Raven, 'Print culture and the perils of practice', p. 218.
} 
- To provide a local, regional, national and international means of exchanging information, skills and expertise in printing history and culture;

- To engage in and support ground-breaking interdisciplinary research into printing history and culture;

- To seek partnerships between universities, heritage organisations, independent scholars, businesses and practitioners to sponsor and encourage the investigation and understanding of printing history and culture;

- To promote the transfer and exchange of knowledge of printing history and culture amongst individuals and within communities and institutions. ${ }^{16}$

The boundaries of printing history — and print culture for that matter — are wonderfully fluid: print has connected historically, and continues to do so, in various ways to so many aspects of life that to build barriers around its study would be counterproductive. Books per se are considered historically significant primarily because they helped to spread ideas. This was true of manuscript books long before the invention of printing brought about a huge increase in the number of books produced, gradually lowered their cost, and also, importantly, enabled scholars and other readers to compare and refer to books in a much more precise way (assuming they were using the same edition of a particular text) than had ever been possible with handwritten copies. Uniform pagination and annotation within a single printed edition generally enabled leading scholars to correspond with international contacts, citing specific parts of a text, plus notes and references, in a much more precise way than had ever been possible in the age of manuscript. Erasmus of Rotterdam is the example par excellence of the early modern scholar making imaginative and effective use of printed texts within a dynamic network of other scholars throughout Europe. At the same time he was

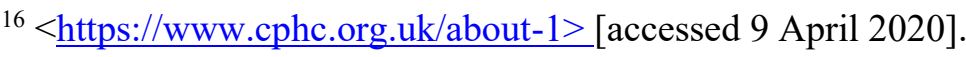


creatively using the medium of print to construct his own 'image' in what seems a very modern way. ${ }^{17}$

While the new technology of printing undoubtedly gave a boost to scholarly activities and made a considerable contribution to the spread of knowledge, it does need to be borne in mind that some of the new-fangled printed books of the fifteenth century also had the more negative effect of entrenching old and outdated ideas which might have been better left behind in the past. Yet another controversy: there was for some time an over-emphasis on the history of scholarly books. Important though these were, the printing press also helped many kinds of popular culture to develop and thrive, through the production of cheap literature, such as chapbooks, songsters and ballad-sheets, as well as posters and handbills advertising popular theatrical, musical and sporting events. ${ }^{18}$

Did all this new activity constitute a 'printing revolution'? For some time, this question proved highly controversial. The transition from manuscript to print culture during the late medieval and early modern periods understandably holds a particular fascination. The gradual but steady increase in literacy, together with improvements in education - combined with technological advances which brought about the development of printing - mark a significant cultural shift in history, but it was not one that happened overnight. Scholars of manuscript studies point out that the introduction of printing did not supersede the production of handwritten texts at one fell swoop. Countering the assertions of those he called 'print

\footnotetext{
${ }^{17}$ L. Jardine, Erasmus, Man of Letters: the Construction of Charisma in Print (New Jersey: Princeton University Press, 1993).

${ }^{18}$ Early exceptions were two very influential studies: R. D. Altick, The English Common Reader: a social history of the mass reading public 1800-1900 (Chicago University Press, 1957) and V. E. Neuburg, Popular Literature: a History and Guide: from the beginning of printing to the year 1897 (Harmondsworth: Penguin Books, 1977). Altick's subtitle is misleading, as his first three chapters cover earlier periods. More recently, much has been published about cheap and popular print; see for example a special issue of Publishing History, 70 (2011).
} 
triumphalists', Harold Love argued convincingly that 'the advent of the press did not extinguish older methods of publication through manuscript' ${ }^{19}$

As so often happens with past controversies, viewed from a distance in time, it can be appreciated that both sides of the argument are to some extent significantly correct. ${ }^{20}$ The emergence of a culture of print in Britain, and in Europe as a whole, may have been evolutionary rather than revolutionary, but this does not negate the persuasive arguments of Elizabeth Eisenstein, a distinguished champion of the 'printing revolution' hypothesis. ${ }^{21}$ Some of the features of print culture which she describes can be identified in provincial England. However, Eisenstein's inspirational but sometimes sweeping assertions benefit from being tempered by other views, including those of Adrian Johns. ${ }^{22}$ By examining the book trade and its internal relationships in greater depth than Eisenstein, he argues that 'far from being a coherent and revolutionary agent of change, the printed book in early modern Europe was an unstable and malleable medium susceptible to a wide range of influences from far beyond its own sphere'. ${ }^{23}$ The printing revolution may have been somewhat less coherent than Eisenstein suggests, but there can be no doubt that the printing press was a powerful agent of change - and remains so even in the present age of digital communication. Signs of the emergence of print in the English Midlands point to an uneven, almost leisurely, process but, once it had taken hold, the impact of print was surely 'revolutionary' by any definition.

\footnotetext{
${ }^{19}$ H. Love, The Culture and Commerce of Texts: Scribal Publication in Seventeenth-Century England (revised edition, Amherst: University of Massachusetts Press, 1998; first published by Oxford University Press, 1993), pp. 3-4.

${ }^{20}$ See for example D. McKitterick, Print, Manuscript and the Search for Order, 1450-1830 (Cambridge: Cambridge University Press, 2003).

${ }^{21}$ E. L. Eisenstein, The Printing Revolution in Early Modern Europe $\left(2^{\text {nd }}\right.$ edn, Cambridge: Cambridge University Press, 2012), an abridged edition of Eisenstein's magnum opus, The Printing Press as an Agent of Change: communications and cultural transformations in early-modern Europe (Cambridge: Cambridge University Press, 1979).

${ }^{22}$ A. Johns, The Nature of the Book: print and knowledge in the making. (Chicago: Chicago University Press, 1998).

${ }^{23}$ J. Feather, 'Revolutions Revisited' (review of A. Johns, The Nature of the Book), SHARP News, vol. 8, no. 4, (Autumn 1999), 10.
} 
Interestingly, Eisenstein discusses in a later essay the term 'revolution' in relation to the spread of printing:

What has happened to the term revolution may be taken as an indication of the kinds of problems that are produced by the cumulative effects of print. For the term has itself been overloaded - made to bear the burden of three distinctively different models of change: circular movement, abrupt rupture, continuous development. Given the workings of print culture, any attempt to limit usage at this point is not only unlikely to succeed, but is also likely to be counterproductive... ${ }^{24}$

She also points to the use of the phrase The Long Revolution by Raymond Williams, ${ }^{25}$ as the title of his seminal study of the spread of literacy, and indicates that she intends 'revolution', as applied to printing, to imply a similar, long-term though far-reaching change. ${ }^{26}$ In addition to clarifying Eisenstein's terminology, this reminds us of the key factor of literacy and its spread, without which a printing revolution, however defined, could never have happened. Eisenstein was also correct in asserting that the coming of printing played a key role in three European movements: the Renaissance, the Reformation, and the birth of modern science. ${ }^{27}$

The new technology of printing arrived in England firstly in London and only gradually spread to the provinces. William Caxton, the leading English merchant in the Low Countries, having spent some time in Cologne, where he realised the opportunities offered by the new craft of printing, returned to his native land in 1476 and set up the first British printing press in Westminster. ${ }^{28}$ His successors moved a short distance to the east into the

\footnotetext{
${ }^{24}$ E. L. Eisenstein, 'On Revolution and the Printed Word', in Revolution in History, ed by R. Porter and M. Teich, (Cambridge: Cambridge University Press, 1986), pp. 186-205, (p. 189).

${ }^{25}$ R. Williams, The Long Revolution (London: Chatto \& Windus, 1961).

${ }^{26}$ Eisenstein, 'On Revolution and the Printed Word', pp. 187-88.

${ }^{27}$ I avoid the term 'Scientific Revolution', an even more vigorously contested term than 'printing revolution'.

${ }^{28}$ L. Hellinga, William Caxton and Early Printing in England (London: British Library, 2010). Caxton was in Cologne from 1471 to 1472, where he commissioned the printing of three Latin books.
} 
City of London, where the area of Fleet Street and St Paul's soon became the principal national centre for the production and distribution of books. Fleet Street later became synonymous with the newspaper press, a position it held until the late twentieth century. The provincial newspaper press is a popular field of historical study, given a refreshing twist in the article by Andrew J. H. Jackson, Claudia Capancioni, Elaine Johnson and Sian HopeJohnson. Their original and entertaining article discusses the origins of women's football, using the local press of Lincoln as their evidence of some very varied attitudes to the emergence of the sport in the early years of the twentieth century. ${ }^{29}$

Any study of British printing needs to acknowledge that Britain lagged behind mainland Europe:

Printing was slow to come to England. By the time the first book printed in England came off a small press in an outbuilding of Westminster Abbey in mid-1476, the art of printing with movable type had been developing on the continent of Europe for about twenty years, and the new technique, perceived as almost magical, was beginning to change the world for ever. ${ }^{30}$

Printing in the Midlands, as in other provincial areas, had a leisurely start. In 1577 Mary I granted a charter to the Stationers' Company which benefitted the London-based stationers and printers by restricting printing to London and the two university towns of Oxford and Cambridge. However, as Colin Clair notes in his standard history of British printing:

At this early stage of printing, some merchants commissioned books, acting in effect as publishers. Caxton was never a 'hands-on' printer but an innovative entrepreneur and translator.

${ }^{29}$ For the history of the provincial newspaper press see H. Barker, Newspapers, Politics and English Society 1695-1855 (Harlow: Longman, 2000) and I. Cawood and L. Peters, eds, Print, Politics and the Provincial Press in Modern Britain (Oxford: Peter Lang Ltd, 2019).

${ }^{30}$ Hellinga, William Caxton, p. 1. 
at the time this made little difference, for what printing there had been elsewhere had already ceased, and the monopoly granted to the Stationers' Company did not result in the closing of any provincial presses. The literate population was so small in most provincial towns at that time that, apart from service books for the churches, there was little scope for a printer. Up to 1557 printing had been introduced into ten towns outside London; these were Oxford, St. Albans, York, Cambridge, Tavistock, Abingdon, Ipswich, Worcester, Canterbury and Norwich. ${ }^{31}$

Following the Restoration, new legislation meant that provincial printing was further restricted until 1695, when the Printing (Licensing) Act was allowed to lapse, although there is evidence of books, both handwritten and printed, being owned, bought and sold in the Midlands long before local printing was permitted. ${ }^{32}$ Some of these books were in Latin and many were imported from mainland Europe.

Following the lifting of restrictions in 1695 , printing gradually became established in many towns in the Midlands and the rest of the country. It is surely not entirely coincidental that this growth of provincial printing coincides with what Peter Borsay identified as the 'English Urban Renaissance', a process in which the printing press played a significant role. ${ }^{33}$ As James Raven observes:

Outside London, the rapid growth of many old market towns, as well as many new settlements, provided the crucial stimulus to the book trade of the period. This is the

\footnotetext{
${ }^{31}$ C. Clair, A History of Printing in Britain (London, Cassell, 1966), p. 112.

${ }^{32}$ My own research on printing and the book trade in Leicester found several such examples: Hinks, History of the Book Trade in Leicester.

${ }^{33} \mathrm{P}$. Borsay, The English Urban Renaissance: culture and society in the provincial town 1660-1770 (Oxford: Oxford University Press, 1989). See also J. Hinks and C. Armstrong, eds.,The English Urban Renaissance Revisited, edited by (Newcastle upon Tyne: Cambridge Scholars Publishing, 2018), which includes a very useful essay by Borsay, reviewing his urban renaissance hypothesis after a quarter-century or so. For Birmingham, see J. Hinks, 'Baskerville's Birmingham: printing and the English urban renaissance' in John Baskerville: art and industry of the Enlightenment, ed by C. Archer-Parré and M. Dick (Liverpool: Liverpool U. P., 2017), pp. 25-41.
} 
century of the English 'urban renaissance' and the growth of the 'leisure town', both issues of recent debate among historians. [...] In England, the advance first of regional printing and newspaper publishing and then (much later) of regional book publishing, is one of the most striking features of the eighteenth-century book trade. In printing, although not in publishing, the 1690 s had been the watershed decade. From mid-century, bookselling and newspaper publishing in the country towns increased sharply. ${ }^{34}$

The urban renaissance was the context within which many leading figures of science, art and industry operated, notably John Baskerville, surely the most famous printer of the Midlands, who features in several of these articles. As Caroline Archer-Parré explains in her article, Baskerville was 'an Enlightenment figure who changed the course of type design'. ${ }^{35}$ The article by Caroline Archer-Parré and Ann-Marie Carey describes a groundbreaking scientific analysis of the punches used by Baskerville, shedding much new light on the practices of this outstanding printer of the eighteenth century.

The unique conditions that shaped the history of printing in England led to a concentration of scholarly studies on London printing, plus a selection of local studies on various provincial towns carried out, for the most part, by 'amateur' historians, though none the worse for that. Unfortunately, the emphasis on London, important though it is, has tended to skew the history of British printing to some extent. This issue of Midland History helps to redress the balance by exploring aspects of provincial printing in central England. I suggested, some years ago, that the time was surely ripe for the development of a history of

\footnotetext{
${ }^{34}$ J. Raven, The Business of Books: booksellers and the English book trade 1450-1850 (New Haven and London: Yale University Press, 2007), p.141. See also J. Feather, A History of British Publishing ( $2^{\text {nd }}$ edn, London: Routledge, 2006).

${ }^{35}$ See Archer-Parré's article in this issue.
} 
printing in the English regions and for the connections between London and the regions to be studied more systematically:

One aspect of the history of provincial printing that may be seen as a new opportunity is the systematic study of regional trade networks at various periods. There has not yet been a great deal of research at regional level, but I would suggest that, after many years of piecemeal local research, we are close to the point where sufficient information has been gathered to enable at least a tentative regional history of printing to be attempted in some parts of the country. At least as important as researching regional printing networks is the identification of book-trade links between the provinces and London. ${ }^{36}$

Provincial printing and bookselling are given some attention in the volumes of The Cambridge History of the Book in Britain $(\mathrm{CHoBB})$ published in seven volumes by Cambridge University Press between 1999 and 2019. ${ }^{37}$

In recent years, printing history has undergone a 'spatial turn', as have social and cultural history more broadly. This has invigorated the field considerably, by focusing attention on the importance of space and place. ${ }^{38}$ This is a key topic discussed in Caroline Archer-Parré's article. An important aspect of the spatial turn is an increasing interest in how printers (and other book-trade people) chose where to trade: not only which town but which

\footnotetext{
${ }^{36}$ J. Hinks, 'Local and Regional Studies of Printing History: Context and Content', Journal of the Printing Historical Society (NS 5, Spring 2003), 3-15 (5-6). See also Historical Networks in the Book Trade, ed. by J. Hinks and C. Feely (London: Routledge, 2017).

${ }^{37}$ See for example: J. Barnard and M. Bell, 'The English Provinces', in CHoBB, vol. IV: 1557-1695 (Cambridge: Cambridge University Press, 2002), pp. 665-686, and M. Bell and J. Hinks, 'The English Provincial Book Trade: evidence from the British Book Trade Index' in $C H o B B$, vol. V: 1695-1830 (Cambridge: Cambridge University Press, 2009), pp. 335-51.

${ }^{38}$ See for example: Geographies of the Book, edited by M. Ogborn and C. W. J. Withers (Farnham: Ashgate, 2010).
} 
location within that town to establish their business. ${ }^{39}$ The aforementioned Ann Ireland obviously chose her location very carefully: her shop and circulating library were situated opposite the Assembly Rooms in Leicester, where the gentry of the town and county congregated, providing Ireland with a regular supply of customers with wide-ranging and fashionable demands. ${ }^{40}$

One Midlands town in particular, Oxford, has long played a major international role in scholarly printing and publishing, through the wide-ranging work of its university press (OUP). Sahar Afshar explains in her article how OUP pioneered printing in Gurmukhi script. This followed OUP's long established practice of designing, casting and setting so-called 'exotic' founts, initially as a scholarly activity but, by the nineteenth century, engaging with British India by publishing books in the various languages of the subcontinent. This reflects yet another controversy: printing history has until recently been seen almost exclusively through the lens of the roman alphabet to the exclusion of what are now known as 'global scripts' and which collectively are used by more people worldwide than the roman alphabet.

The spatial turn also liberated the geographical scope of the field by recognising that national boundaries are not always the most appropriate for historical surveys, even for a period (roughly before the mid nineteenth-century) when the nation-state was still emerging as a new phenomenon: '[the] transnational perspective, loosely defined as studying cultural flows across political boundaries, is both a legitimate and helpful approach for this period'. ${ }^{41}$

\footnotetext{
${ }^{39}$ For London, see J. Raven, Bookscape: geographies of printing and publishing in London before 1800 (London: British Library, 2014); for Birmingham, see M. Dick, 'The Topographies of a Typographer: mapping John Baskerville since the eighteenth century', in John Baskerville: art and industry of the Enlightenment, ed. by C. Archer-Parré and M. Dick (Liverpool: Liverpool University Press, 2017), pp. 9-24.

${ }^{40}$ Advertisement in the Leicester Journal, 14 October 1786. Following the death of her husband, she had to vacate his shop and relocate.

${ }^{41}$ Leisure Cultures in Urban Europe, c.1700-1870: a transnational perspective, ed. by P. Borsay and J. H. Furnée (Manchester: Manchester University Press, 2016), p. 7. See also The Spatial Turn: interdisciplinary perspectives, ed. by B. Warf and S. Arias (London: Routledge, 2008).
} 
The articles in this issue range widely in both topic and chronological focus but they benefit from a unifying, if many-faceted, approach to the history of printing and print culture in many of its diverse manifestations.

Print has played a key role in many historical movements, not least in the 'Midlands Enlightenment', an increasingly popular area of study. ${ }^{42}$ As Caroline Archer-Parré explains, print had a part to play in this 'cultural manifestation that created the space in which science, art and industry could exchange ideas, where social, cultural and industrial interactions could be forged which in turn facilitated rapid industrial and economic growth' ${ }^{43}$ That sentence sums up the essence of the history of printing and print culture: a pivotal role where technology, art, science and creativity respond to, and in turn contribute to, so many aspects of life. This issue of Midland History aims to explain, by means of carefully chosen casestudies, how this fascinating process has manifested itself through the centuries since the invention of printing, right down to the present day.

\footnotetext{
${ }^{42}$ See for example P. M. Jones, Industrial Enlightenment: science, technology and culture in Birmingham and the West Midlands 1760-1820 (Manchester: Manchester University Press, 2008); British Journal for Eighteenth-Century Studies (30:2, 2007), special issue, 'Science and the Midlands Enlightenment'.

${ }^{43}$ See Archer-Parré's article in this issue.
} 